\title{
Determination of Common Analytes at Trace Levels in Zr Matrix by ICP-AES Without Chemical/Physical Separation
}

\author{
Arijit Sengupta* and V.C. Adya \\ Radiochemistry Division, Bhabha Atomic Research Centre \\ Mumbai, India
}

\section{INTRODUCTION}

Trace metallic impurity analysis is one of the prime steps in chemical quality control of nuclear fuels and associated materials. To achieve the desired burn-up, successful life span of the fuel in the reactor, and successful running of the reactor, it is required to have stringent physical and chemical quality control and quality assurance measures of the nuclear fuels and associated materials. The atomic emission spectroscopy (AES) technique, being simultaneously multi-elemental and having acceptable analytical performance (detection limits, sensitivity, linear dynamic range, etc.), is regularly used for the determination of trace metallic analytes in nuclear fuels and associated materials (1-17). Zirconium $(\mathrm{Zr})$ is accepted worldwide as a cladding material in the nuclear industry due to its low neutron absorption cross-section. U-Zr, $\mathrm{U}-\mathrm{Pu}-\mathrm{Zr}, \mathrm{Zr}-\mathrm{Nb}$, etc., and binary and ternary alloy materials are also gaining importance as nuclear fuels and associated materials in the nuclear industries (18-27). Thus, there is a need for developing a method for the determination of trace constituents in a $\mathrm{Zr}$ matrix. Due to its line-rich emission spectra, the presence of $\mathrm{Zr}$ even at trace levels can lead to the over-estimation of analytes due to spectral interferences. For the determination of trace metallic constituents, they either have to be separated physically from the trace metals using the d.c.

*Corresponding author

E-mail: arijita@barc.gov.in

\section{ABSTRACT}

Chemical (ICP-AES) or physical (d.c. arc carrier distillation technique) separation of the major matrix, followed by the determination of trace metallic impurities in the raffinate, is a well accepted protocol in the nuclear industries to avoid spectral interferences from emissionrich matrices such as $\mathrm{U}, \mathrm{Pu}, \mathrm{Zr}$, Th, etc. With ICP-AES analysis, the RSD is better (less than 5\%), separation is time-consuming, involves handling of the materials which increases the chances of contamination, while the precision of the d.c. arc technique is $15-25 \%$. Thus, there is a need to have an ICP-AES-based methodology where the analytes can be determined in a nuclear matrix at trace levels without requiring chemical separation.

In this paper, an attempt was made to develop a method for the determination of trace constituents in a $\mathrm{Zr}$ matrix without separation by using the flexibility of a charge coupled device (CCD) detector for choosing additional interference-free analytical lines for $\mathrm{Mn}, \mathrm{Fe}, \mathrm{Ga}, \mathrm{In}, \mathrm{Sr}$, $\mathrm{K}, \mathrm{Li}, \mathrm{Eu}, \mathrm{Co}, \mathrm{Zn}, \mathrm{Ni}, \mathrm{Cu}, \mathrm{Al}$, and Si. It was observed that the analytes can be determined up to $0.1 \mu \mathrm{g} / \mathrm{mL}$ in the presence of $\mathrm{Zr}$. The results were also compared with routinely used methods and found to be satisfactory. In addition, an analytical method was developed for the determination of zirconium by ICP-AES, including the identification of suitable analytical lines $(343.823 \mathrm{~nm}$, $257.139 \mathrm{~nm}$, and $272.262 \mathrm{~nm}$ ) and studying the analytical performance such as sensitivity, detection limits, etc. arc carrier distillation technique (1-6) or by chemical separation, followed by ICP-AES analysis of the raffinate (7-15). Different approaches were found in the literature for the determination of analytes in $\mathrm{Zr}$ matrices (28-29).

In d.c arc, where sample handling is less and thus also the chances of less contamination, the method suffers from poor precision. In ICPAES, where more sample handling is required during chemical separation of the major matrix, the chances of contamination are greater but the detection limits as well as precision are better than with the d.c. arc carrier distillation technique. In ICP-AES, a suitable extractant and feed conditioning are required resulting in preferential extraction of the major matrix without loss of the analytes even at trace levels. Therefore, a method needs to be developed where sample handling is minimum and the analytical performance of the method (precision, detection limits, linear dynamic range, sensitivity, etc.) superior. In our previous study (30-31), an attempt was made to understand the spectral interference of uranium on other analytes using CCD-based ICP-AES.

In the present study, a method was developed for the determination of Mn, Ga, Sr, Li, Eu, Co, Zn, $\mathrm{Ni}, \mathrm{Cu}$, and Si using a charge coupled device (CCD) detector without requiring any physical or chemical separation. The CCDbased detector provides the option of choosing additional analytical lines free from $\mathrm{Zr}$ interference as listed in Table I. 
The present method was compared with two existing methods for the determination of trace metallic constituents in a $\mathrm{Zr}$ matrix: ICP-AES analysis after quantitative removal of the major matrix without loss of impurities at trace levels and d.c. arc carrier distillation technique where trace constituents are swept out physically into the arc while the matrix remains in the electrode. The analytical performance was found to be comparable and satisfactory. Also, an analytical method was developed for the determination of $\mathrm{Zr}$ which involves identification of suitable analytical lines of $\mathrm{Zr}$ (339.198 nm, $343.823 \mathrm{~nm}$, $257.139 \mathrm{~nm}$, and $272.262 \mathrm{~nm}$ ) and the analytical performance (detection limits, sensitivity, etc.) of those lines, etc., was investigated.

\section{EXPERIMENTAL}

\section{Instrumentation}

The analytical experiments were carried out using a computer-controlled, high resolution, simultaneous inductively coupled plasma atomic emission spectrometer (ICPAES) (Spectro Arcos, Germany),

TABLE I

Interference-free Lines for Analytes in Zr Matrix

\begin{tabular}{ll}
\hline $\mathrm{Mn}$ & $257.611 \mathrm{~nm}$ \\
$\mathrm{Fe}$ & $259.941 \mathrm{~nm}, 261.187 \mathrm{~nm}$ \\
$\mathrm{Co}$ & $230.786 \mathrm{~nm}$ \\
$\mathrm{Ni}$ & $231.604 \mathrm{~nm}, 221.648 \mathrm{~nm}$ \\
$\mathrm{Cu}$ & $324.754 \mathrm{~nm}$ \\
$\mathrm{Ga}$ & $417.206 \mathrm{~nm}$ \\
$\mathrm{In}$ & $230.606 \mathrm{~nm}$ \\
$\mathrm{Si}$ & $212.412 \mathrm{~nm}, 251.612 \mathrm{~nm}$ \\
$\mathrm{Sr}$ & $421.552 \mathrm{~nm}$ \\
$\mathrm{~K}$ & $766.491 \mathrm{~nm}$ \\
$\mathrm{Li}$ & $670.780 \mathrm{~nm}$ \\
$\mathrm{Eu}$ & $420.505 \mathrm{~nm}, 381.967 \mathrm{~nm}$, \\
& $393.048 \mathrm{~nm}, 390.710 \mathrm{~nm}$ \\
$\mathrm{Zn}$ & $213.856 \mathrm{~nm}, 206.200 \mathrm{~nm}$ \\
$\mathrm{Al}$ & $394.401 \mathrm{~nm}$ \\
\hline
\end{tabular}

with ICP and d.c. arc as the excitation sources and a charge coupled device (CCD) as the detector. The instrumental specifications and experimental parameters are summarized in Table II. The detector system, consisting of linear arrays of the CCD detector (3648 pixels/array), thermally stabilized together with an optical system, provides the ability to choose alternate analytical lines.

\section{Standard Solutions and Reagents}

The standard solutions for rare earth and other common impurity elements were prepared from CertiPUR ${ }^{\circledR}$ ICP multi-standard solutions (E-Merck, Darmstadt, Germany) by proper dilution with $0.5 \mathrm{M} \mathrm{HNO}_{3}$. Suprapur ${ }^{\circledR} \mathrm{HNO}_{3}$ (E-Merck, Darmstadt, Germany) and quartz doubly distilled water were used for making $0.5 \mathrm{M} \mathrm{HNO}_{3}$. Multipoint standardization was carried out using $0.5 \mathrm{M} \mathrm{HNO}_{3}$ as the lower standard and $0.05-1000 \mu \mathrm{g} / \mathrm{mL}$ of the corresponding elemental standard as the higher standard for each line after proper peak search. To understand the spectral interference of $\mathrm{Zr}$ on other analytes, pure $\mathrm{Zr}$ solutions of different concentrations were used and the contributions at each analytical channel monitored.

For the analytical lines, having contribution from $1000 \mu \mathrm{g} / \mathrm{mL} \mathrm{Zr}$, $\leq 0.05 \mu \mathrm{g} / \mathrm{mL}$ was considered as free from spectral interference from $\mathrm{Zr}$ (the correction factor being negligibly small). For the determination of trace analytes, these interference-free lines were taken. The synthetic samples were

TABLE II

ICP-AES Specifications and Operating Conditions

\begin{tabular}{|c|c|c|}
\hline \multicolumn{3}{|c|}{ Instrumental Specifications } \\
\hline Model & \multicolumn{2}{|c|}{ Arcos FHS12 ICP-AES } \\
\hline Optical design & \multicolumn{2}{|c|}{ Paschen-Runge mounting, circular design } \\
\hline Focal length & \multicolumn{2}{|c|}{$750 \mathrm{~mm}$} \\
\hline Grating & \multicolumn{2}{|c|}{ Holographic } \\
\hline Groove density & \multicolumn{2}{|c|}{1800 grooves/mm (1), 3600 grooves/mm (2) } \\
\hline Wave length range & \multicolumn{2}{|c|}{$130-800 \mathrm{~nm}$} \\
\hline Entrance slit width & \multicolumn{2}{|c|}{15 microns } \\
\hline Resolution (FWHM) & \multicolumn{2}{|c|}{$0.01 \mathrm{~nm}$ from $130-450 \mathrm{~nm}$} \\
\hline & \multicolumn{2}{|c|}{$0.02 \mathrm{~nm}$ from $450-800 \mathrm{~nm}$} \\
\hline Thermal regulation & \multicolumn{2}{|c|}{ Controlled to $30 \pm 1^{\circ} \mathrm{C}$} \\
\hline Frequency & \multicolumn{2}{|c|}{$27.12 \mathrm{MHz}$} \\
\hline Pump & \multicolumn{2}{|c|}{ Dual channel peristaltic pump } \\
\hline Detector & \multicolumn{2}{|c|}{ Linear arrays of CCD (3648 pixels/array) } \\
\hline Nebulizer & \multicolumn{2}{|c|}{ Concentric nebulizer with cyclonic spray chamber } \\
\hline ICP-torch & \multicolumn{2}{|c|}{ Demountable, radial viewing } \\
\hline \multicolumn{3}{|l|}{ Operating Conditions } \\
\hline \multicolumn{2}{|l|}{ Coolant flow } & $6 \mathrm{~L} / \mathrm{min}$ \\
\hline \multicolumn{2}{|l|}{ Auxiliary flow } & $0.6 \mathrm{~L} / \mathrm{min}$ \\
\hline \multicolumn{2}{|c|}{ Total time of measurement } & $28 \mathrm{~s}$ \\
\hline \multicolumn{2}{|l|}{ Pump speed } & $30 \mathrm{rpm}$ \\
\hline \multicolumn{2}{|l|}{ RF power out put } & $0.8-1.5 \mathrm{~kW}$ \\
\hline \multicolumn{2}{|l|}{ Input power } & $230 \mathrm{~V} \mathrm{AC}$ \\
\hline
\end{tabular}




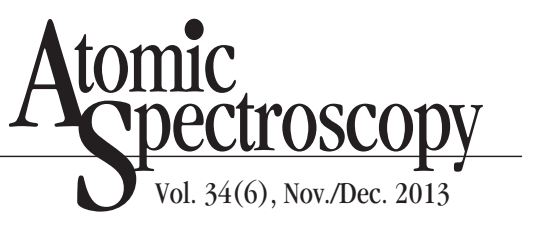

prepared by dissolving high purity $\mathrm{ZrO}_{2}$ (locally prepared and checked by inter-laboratory comparison experiments involving different laboratories of the Department of Atomic Energy, India) with $0.005 \%$ $\mathrm{HF}-\mathrm{HNO}_{3}$ by heating under an IR lamp (temperature $\sim 80^{\circ} \mathrm{C}$ ). The fluoride ion was removed completely by repeated heating with concentrated $\mathrm{HNO}_{3}$. Finally, the acidity of the sample solution was brought to $\sim 1 \mathrm{M} \mathrm{HNO}$. Then it was spiked with appropriate aliquots of the analytes for the preparation of synthetic samples and used for the ICP-AES experiments.

The routinely adopted method for trace metal assay in a $\mathrm{Zr}$ matrix is chemical separation of $\mathrm{Zr}$ (quantitatively) from the analytes using $30 \%$ TBP-dodecane (five contacts) from an aqueous solution of $\sim 4 \mathrm{M}$ $\mathrm{HNO}_{3}$, followed by feeding of the aqueous phase into the plasma for analysis. The above-mentioned routine procedure was adopted and the data were compared with the newly developed methods.

The analytical results were also compared with the method of determination of those trace analytes in the same solid $\mathrm{ZrO}_{2}$ matrix using the d.c. arc carrier distillation technique [5\% carrier consisting of a mixture of $\mathrm{AgCl}$ and $\mathrm{SrF}_{2}$ (4:1)] using the same instrument (also attached with d.c. arc excitation source). The comparison was found to be satisfactory.

\section{RESULTS AND DISCUSSION}

The overall work of this study can broadly be divided into three sections for discussion: (a) Determination of zirconium by ICP-AES involving the development of the ICP-AES-based methodology for the determination of $\mathrm{Zr}$ and includes indentification of the different emission lines of $\mathrm{Zr}$, establishing calibration curves, and studying their analytical performance such as detection limits, sensitivity, etc. (b) Detailed study of the spectral interferences of zirconium on the analytes on different analytical channels along with their analytical performance. (c) Development of a method for the determination of the analytes without chemical separation. In this segment, based on the spectral interference study (previous section), an attempt was made to develop a method for the determination of the analytes in a $\mathrm{Zr}$ matrix without separation and the analytical results were compared with routinely used methods.

\section{ICP-AES Determination of $\mathrm{Zr}$}

Zirconium is a multi-electronic system with line-rich emission spectra. Due to the availability of different emission lines, the sensitivity of the lines were found to be less and the detection limits poorer with a photo multiplier tube (PMT)based detection system. Exploring the superior analytical performance of the CCD-based detector system, an analytical method was developed for the determination of $\mathrm{Zr}$ by ICPAES. This study includes identification of suitable analytical lines. Four emission lines of $\mathrm{Zr}$ were identified (257.139 nm, $272.262 \mathrm{~nm}$, $339.198 \mathrm{~nm}$, and $343.823 \mathrm{~nm}$ ), and the calibration curves established (see Figure 1). The emission profiles of the different analytical lines of $\mathrm{Zr}$ mentioned in the present case are shown in Figure 2 (A, B, C, and D). It was found that the 257.139 $\mathrm{nm}, 272.262 \mathrm{~nm}$, and $343.823 \mathrm{~nm}$ lines can be used for the determination of Zr up to $1000 \mu \mathrm{g} / \mathrm{mL}$ with an RSD of less than 5\%, while for the $339.198 \mathrm{~nm}$ line, $200 \mu \mathrm{g} / \mathrm{mL}$ is the upper limit of detection for $\mathrm{Zr}$ (Table III). The sensitivity and detection limits of $\mathrm{Zr}$ using the above-mentioned analytical lines were evaluated using the slopes of the calibration curves and the concentration equivalent to the inten-

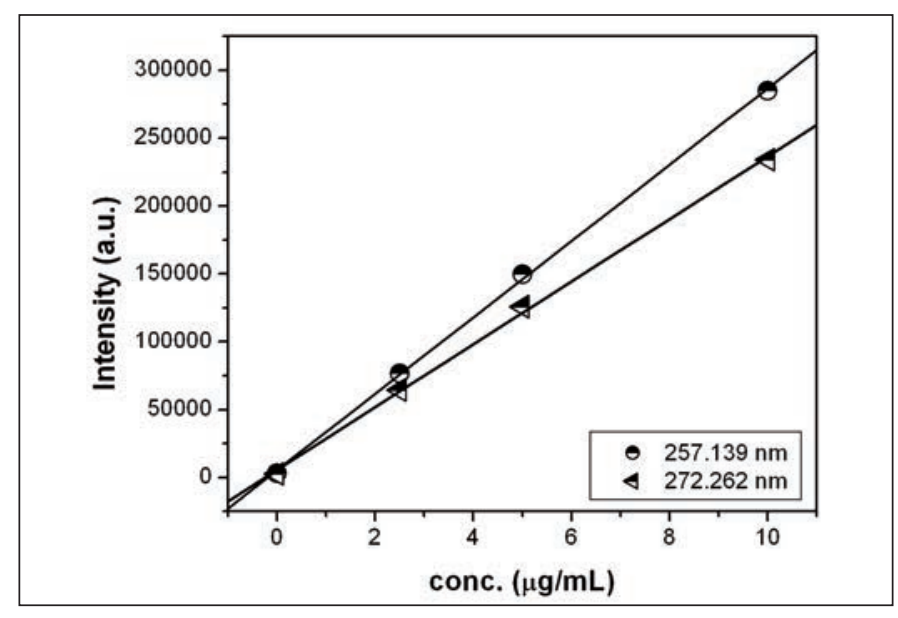

Fig. 1(A). Calibration curves for $\mathrm{Zr}$ :

$257.139 \mathrm{~nm}$ and $272.262 \mathrm{~nm}$.

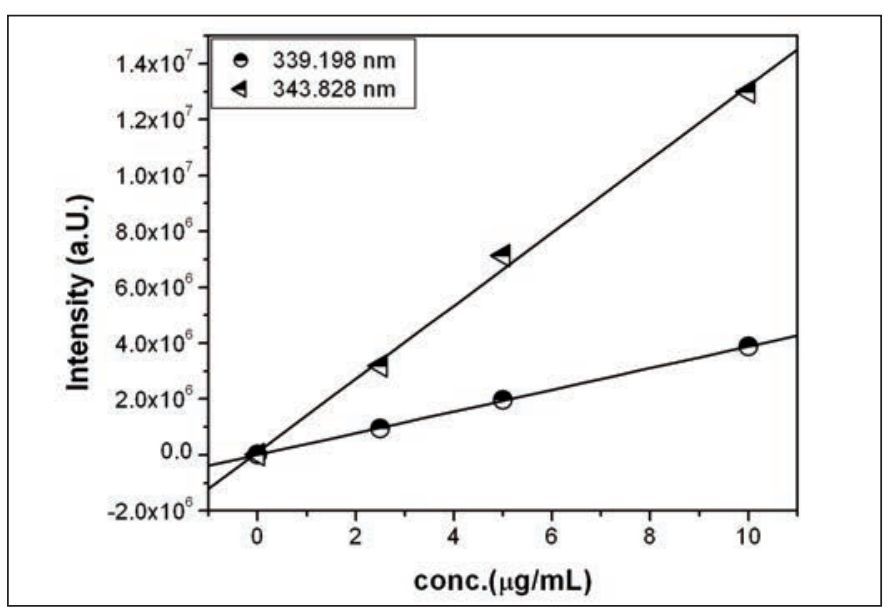

Fig. 1(B). Calibration curves for $\mathrm{Zr}$ : $339.198 \mathrm{~nm}$ and $343.828 \mathrm{~nm}$. 

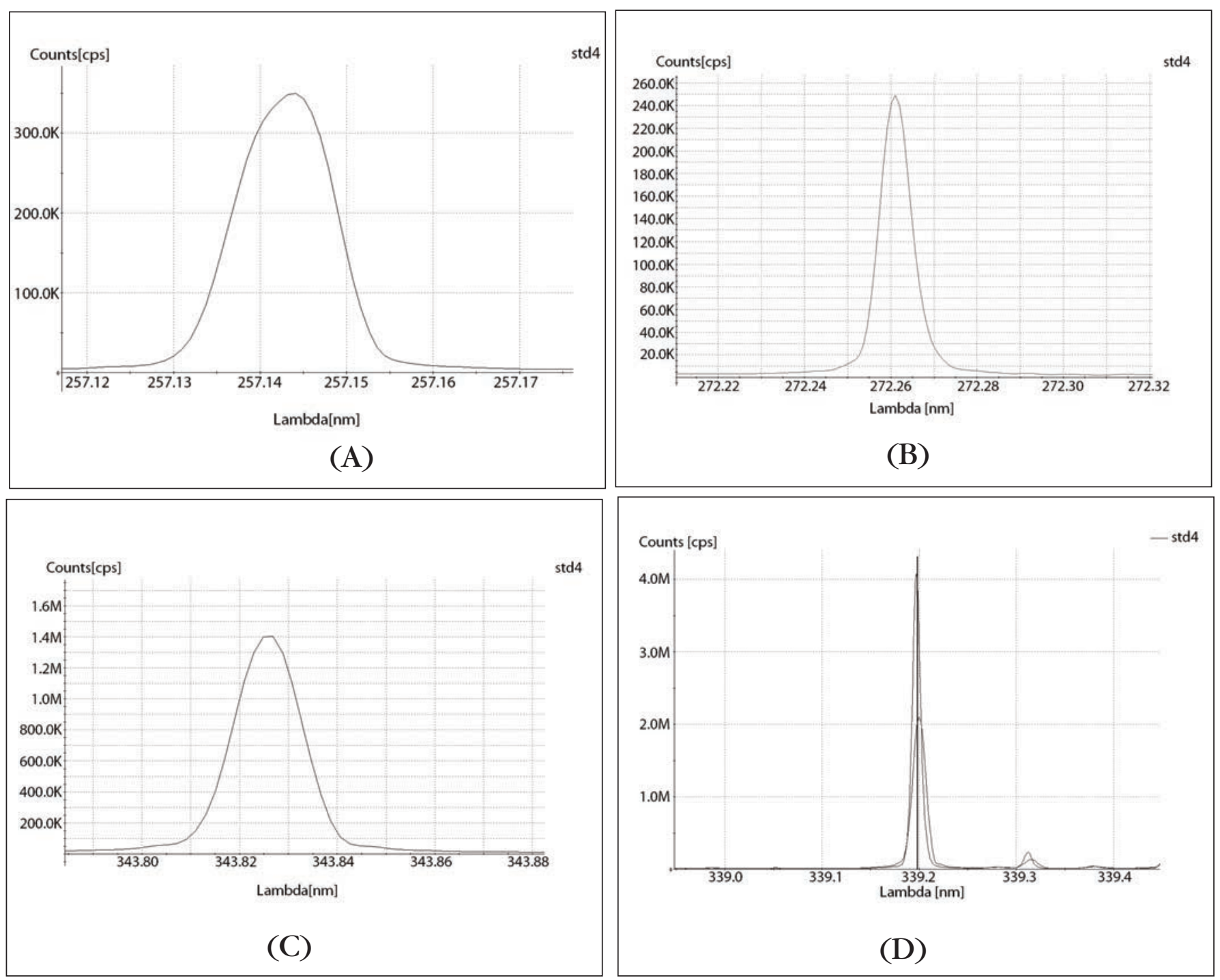

Fig. $2(A, B, C$, and D). Emission profiles of the different analytical lines of $Z r$.

(A) $-257.139 \mathrm{~nm},(B)-272.262 \mathrm{~nm},(C)-343.823 \mathrm{~nm},(D)-339.198 \mathrm{~nm}$.

\section{TABLE III}

Determination of $\mathrm{Zr}$ by ICP-AES

\begin{tabular}{|c|c|c|c|c|c|c|c|c|c|}
\hline $\begin{array}{l}\mathrm{Zr} \text { conc. } \\
(\mathrm{mg} / \mathrm{L})\end{array}$ & $\begin{array}{c}\mathrm{Zr} \\
339.198 \mathrm{~nm} \\
\end{array}$ & $\begin{array}{c}\mathrm{Zr} \\
343.823 \mathrm{~nm} \\
\end{array}$ & $\begin{array}{c}\mathrm{Zr} \\
257.139 \mathrm{~nm} \\
\end{array}$ & $\begin{array}{c}\mathrm{Zr} \\
272.262 \mathrm{~nm} \\
\end{array}$ & $\begin{array}{l}\mathrm{Zr} \text { conc. } \\
(\mathrm{mg} / \mathrm{L})\end{array}$ & $\begin{array}{c}\mathrm{Zr} \\
339.198 \mathrm{~nm}\end{array}$ & $\begin{array}{c}\mathrm{Zr} \\
343.823 \mathrm{~nm}\end{array}$ & $\begin{array}{c}\mathrm{Zr} \\
257.139 \mathrm{~nm} \\
\end{array}$ & $\begin{array}{c}\mathrm{Zr} \\
272.262 \mathrm{~nm}\end{array}$ \\
\hline Blank & $\mathrm{BDL}$ & $\mathrm{BDL}$ & $\mathrm{BDL}$ & BDL & 20 & 20.6 & 21.5 & 21.3 & 21.3 \\
\hline 0.05 & 0.049 & 0.047 & 0.055 & 0.048 & 50 & 49.1 & 54.1 & 52.6 & 50.8 \\
\hline 0.10 & 0.10 & 0.10 & 0.113 & 0.104 & 100 & 97.7 & 102.1 & 106.5 & 102.9 \\
\hline 0.50 & 0.51 & 0.55 & 0.53 & 0.48 & 200 & 185.7 & 199.54 & 209.3 & 201.6 \\
\hline 1 & 1.03 & 1.05 & 1.08 & 1.03 & 500 & 337.2 & 471.2 & 482.5 & 474.2 \\
\hline 2 & 2.05 & 2.15 & 2.14 & 2.125 & 1000 & 339.0 & 845.7 & 952.5 & 919.3 \\
\hline 5 & 5.04 & 5.47 & 5.25 & 5.06 & Detectiol & & 0.09 & 0.34 & 0.12 \\
\hline 10 & 10.3 & 10.5 & 10.6 & 10.4 & \multicolumn{2}{|c|}{ Limit $(\mu \mathrm{g} / \mathrm{mL})$} & & & \\
\hline
\end{tabular}


sity equal to the average of the blank value + three times the standard deviation of the above measurements, i.e., $x+3 \sigma$. According to the analytical performance, the $343.823 \mathrm{~nm}$ line was found to be the best of the four analytical lines mentioned.

\section{Spectral Interference of $\mathrm{Zr}$ on the Analytes}

Interference may originate from various transitions of the complex system, which transforms the sample concentration into equivalent radiation. Among various kinds of interferences, spectral interference is significant as far as ICP-AES is concerned. Usually, for the determination of a particular analyte at the trace level, the most sensitive line is chosen, while if the particular line is overlapped by some interfering line, some other line needs to be selected which may be less sensitive and with poor detection limits. Improvement of the resolving power of the instrument may resolve the lines only if the optics are responsible for spectral overlap. If overlap of the lines is from the broadening process occurring in the plasma, improvement of the instrumental resolution will be inefficient. Therefore, alternative emission lines need to be investigated for their analytical applications. In some cases, it may happen that only the analytical line, which is not strongly interfered, has to be chosen for the analytical purpose. For these lines, appropriate correction factors need to be evaluated.

In the present case and due to the advancement of detector systems, i.e., array of pixels of a CCD detector, there is the option to choose an analytical line in order to avoid spectral interferences. A detailed examination was made to study the spectral interference of $\mathrm{Zr}$ on 14 analytes (see Table IV) and to choose the appropriate emission lines for trace determina- tion of these elements in the presence of a $\mathrm{Zr}$ matrix.

\section{Mn}

Five lines of Mn (257.611 nm, $259.373 \mathrm{~nm}, 260.569 \mathrm{~nm}, 294.921$ $\mathrm{nm}$, and $403.076 \mathrm{~nm}$ ) were investigated. It was observed that there was practically no spectral interference from $\mathrm{Zr}$ on the former three lines, while the remaining two interfered significantly. The lowest detection limit was at the 257.611 $\mathrm{nm}$ line and, therefore, found to be the best for Mn determination in a Zr matrix.

\section{Fe}

Iron $(\mathrm{Fe})$ is one of the elements having line-rich emission spectra. Therefore, ten different analytical lines of Fe (259.941 nm, 238.204 $\mathrm{nm}, 239.562 \mathrm{~nm}, 244.451 \mathrm{~nm}$, $261.187 \mathrm{~nm}, 262.567 \mathrm{~nm}, 262.829$ $\mathrm{nm}, 275.573 \mathrm{~nm}, 241.331 \mathrm{~nm}$, and $373.486 \mathrm{~nm}$ ) were studied. It was found that all of these lines showed moderate spectral interference either due to the presence of wings of the nearby $\mathrm{Zr}$ line or an overall increase in background. Figure 3 represents the typical contribution of $1000 \mu \mathrm{g} / \mathrm{mL}$ of $\mathrm{Zr}$ on the 238.204 $\mathrm{nm}$ and $239.562 \mathrm{~nm}$ analytical lines of Fe. Of all the mentioned lines, the $259.941 \mathrm{~nm}$ and $261.187 \mathrm{~nm}$ lines showed less spectral interference because there was no nearby $\mathrm{Zr}$ line or no appreciable increase in background intensity at these wavelengths due to $\mathrm{Zr}$. Luckily, the interference-free lines were found to have better analytical performance.

\section{Co}

The $237.862 \mathrm{~nm}$ line of Co showed considerable spectral interference from $\mathrm{Zr}$, while the other three lines (228.616 nm, 238.892 $\mathrm{nm}$, and $230.862 \mathrm{~nm}$ ) were relatively interference-free. The $230.786 \mathrm{~nm}$ line of Co is considered to be the best choice for its determination in a $\mathrm{Zr}$ matrix.

\section{Ni}

For $\mathrm{Ni}$, the $231.604 \mathrm{~nm}$ and $221.648 \mathrm{~nm}$ lines were found to be practically interference-free from $\mathrm{Zr}$, while the $232.003 \mathrm{~nm}, 227.021$ $\mathrm{nm}$, and $300.249 \mathrm{~nm}$ lines showed considerable spectral interference. The $174.828 \mathrm{~nm}$ and $341.476 \mathrm{~nm}$ lines for Ni were strongly interfered by $\mathrm{Zr}$ and thus are not at all recommended for the present case. The situation is simple for $\mathrm{Ni}$, because the least interfered lines were found to have the best analytical performance.

Cu

The $\mathrm{Cu} 324.754 \mathrm{~nm}$ and $224.700 \mathrm{~nm}$ lines were found to have least spectral interference from $\mathrm{Zr}$, where the former line also has the lowest detection limits out of all the other lines studied (324.754 nm, $327.396 \mathrm{~nm}$, $224.700 \mathrm{~nm}, 219.226 \mathrm{~nm}$, and $219.958 \mathrm{~nm}$ ). Therefore, it is recommended to use the $324.754 \mathrm{~nm}$ line for the determination of $\mathrm{Cu}$ in a $\mathrm{Zr}$ matrix.

\section{Ga}

Even though the $287.424 \mathrm{~nm}$ and $294.364 \mathrm{~nm}$ lines of Ga showed better analytical performance, there was considerable spectral interference from $\mathrm{Zr}$, while the $417.206 \mathrm{~nm}$ line of $\mathrm{Ga}$ was found to have one order of magnitude higher detection limit than that of the former two lines and had practically no spectral interference. The $141.444 \mathrm{~nm}$ line of Ga was found to have poor analytical performance as well as strong interference from $\mathrm{Zr}$.

\section{In}

For In at the $230.606 \mathrm{~nm}$ line, it was observed that there was some interference and the detection limit of this line was also acceptable. The other analytical lines of In $(325.609 \mathrm{~nm}$ and $303.936 \mathrm{~nm})$ had strong interference from $\mathrm{Zr}$. Therefore, the $230.606 \mathrm{~nm}$ line can be 
TABLE IV

Spectral Interference of $\mathrm{Zr}$ on Different Analytes

\begin{tabular}{|c|c|c|c|c|c|c|c|c|c|c|c|}
\hline Elemer & $\begin{array}{l}\text { Line } \\
\text { t }(\mathrm{nm})\end{array}$ & $\begin{array}{c}\text { Contri- } \\
\text { bution } \\
(\mu \mathrm{g} / \mathrm{mL})\end{array}$ & $\begin{array}{l}\text { Correc- } \\
\text { tion } \\
\text { Factor }\end{array}$ & $\begin{array}{c}\text { D.L. } \\
(\mu \mathrm{g} / \mathrm{mL})\end{array}$ & $\begin{array}{c}\text { Sensitivity } \\
\text { (counts/ } \\
\mu \mathrm{g} / \mathrm{mL} \text { ) }\end{array}$ & Element & $\begin{array}{l}\text { Line } \\
(\mathrm{nm})\end{array}$ & $\begin{array}{l}\text { Contri- } \\
\text { bution } \\
(\mu \mathrm{g} / \mathrm{mL})\end{array}$ & $\begin{array}{l}\text { Correc- } \\
\text { tion } \\
\text { Factor }\end{array}$ & $\begin{array}{c}\text { D.L. } \\
(\mu \mathrm{g} / \mathrm{mL})\end{array}$ & $\begin{array}{r}\text { Sensitivity } \\
\text { (counts/ } \\
\mu \mathrm{g} / \mathrm{mL} \text { ) }\end{array}$ \\
\hline \multirow[t]{5}{*}{ Mn } & 257.611 & 0.016 & $1.60 \mathrm{E}-05$ & $8.6 \times 10^{-5}$ & $2.1 \times 10^{-6}$ & \multirow[t]{4}{*}{ Ga } & 141.444 & 3.254 & $3.25 \mathrm{E}-03$ & 0.085 & 0.006 \\
\hline & 259.373 & 0.014 & $1.40 \mathrm{E}-05$ & 0.0002 & $2.8 \times 10^{-6}$ & & 417.206 & 0.066 & $6.60 \mathrm{E}-05$ & 0.012 & $5.0 \times 10^{-5}$ \\
\hline & 260.569 & 0.01 & $1.00 \mathrm{E}-05$ & 0.0002 & $3.4 \times 10^{-6}$ & & 294.364 & 0.237 & $2.37 \mathrm{E}-04$ & 0.004 & $7.0 \times 10^{-5}$ \\
\hline & 294.921 & 0.326 & $3.26 \mathrm{E}-04$ & 0.0007 & $9.6 \times 10^{-6}$ & & 287.424 & 0.729 & $7.29 \mathrm{E}-04$ & 0.009 & 0.0002 \\
\hline & 403.076 & 1.212 & $1.21 \mathrm{E}-03$ & 0.0011 & $5.8 \times 10^{-5}$ & \multirow[t]{3}{*}{ In } & 230.606 & 0.23 & $2.30 \mathrm{E}-04$ & 0.01 & 0.00015 \\
\hline \multirow[t]{10}{*}{$\mathbf{F e}$} & 259.941 & 0.135 & $1.35 \mathrm{E}-04$ & 0.0072 & $1.0 \times 10^{-5}$ & & 325.609 & 2.06 & 2.06E-03 & 0.007 & $8.7 \times 10^{-5}$ \\
\hline & 238.204 & 0.142 & $1.42 \mathrm{E}-04$ & 0.007 & $1.0 \times 10^{-5}$ & & 303.936 & 3.265 & $3.27 \mathrm{E}-03$ & 0.007 & 0.0001 \\
\hline & 239.562 & 0.151 & $1.51 \mathrm{E}-04$ & 0.0076 & $1.5 \times 10^{-5}$ & \multirow[t]{3}{*}{ Si } & 251.612 & 0.061 & $6.10 \mathrm{E}-05$ & 0.004 & $4.1 \times 10^{-5}$ \\
\hline & 244.451 & 2.133 & $2.13 \mathrm{E}-03$ & 0.0212 & 0.00086 & & 288.158 & 0.132 & $1.32 \mathrm{E}-04$ & 0.0007 & $5.3 \times 10^{-5}$ \\
\hline & 261.187 & 0.154 & $1.54 \mathrm{E}-04$ & 0.0076 & $2.2 \times 10^{-5}$ & & 212.412 & 0.04 & $4.00 \mathrm{E}-05$ & 0.003 & $5.6 \times 10^{-5}$ \\
\hline & 262.567 & 0.216 & $2.16 \mathrm{E}-04$ & 0.0081 & $8.6 \times 10^{-5}$ & \multirow[t]{3}{*}{ Sr } & 407.771 & 0.011 & $1.10 \mathrm{E}-05$ & $4.1 \times 10-5$ & $2.7 \times 10^{-7}$ \\
\hline & 262.829 & 0.398 & $3.98 \mathrm{E}-04$ & 0.0054 & $8.5 \times 10^{-5}$ & & 421.552 & 0.015 & $1.50 \mathrm{E}-05$ & $1.5 \times 10-6$ & $4.0 \times 10^{-7}$ \\
\hline & 275.573 & 0.235 & $2.35 \mathrm{E}-04$ & 0.0081 & $7.4 \times 10^{-5}$ & & 460.733 & 0.062 & $6.20 \mathrm{E}-05$ & 0.020 & 0.0001 \\
\hline & 241.331 & 0.238 & $2.38 \mathrm{E}-04$ & 0.0054 & $8.3 \times 10^{-5}$ & $\mathbf{K}$ & 766.491 & 0.109 & $1.09 \mathrm{E}-04$ & 0.02 & 0.0003 \\
\hline & 373.486 & 0.449 & $4.49 \mathrm{E}-04$ & 0.0081 & 0.0001 & $\mathbf{L i}$ & 670.78 & 0.005 & $5.00 \mathrm{E}-06$ & 0.0001 & $4.2 \times 10^{-6}$ \\
\hline \multirow[t]{4}{*}{ Co } & 228.616 & 0.027 & $2.70 \mathrm{E}-05$ & 0.0011 & $1.5 \times 10^{-5}$ & \multirow[t]{4}{*}{$\mathbf{E u}$} & 420.505 & 0.01 & $1.00 \mathrm{E}-05$ & 0.0006 & $2.9 \times 10^{-6}$ \\
\hline & 238.892 & 0.036 & $3.60 \mathrm{E}-05$ & 0.0008 & $1.5 \times 10^{-5}$ & & 381.967 & 0.026 & $2.60 \mathrm{E}-05$ & 0.0001 & $2.1 \times 10^{-6}$ \\
\hline & 230.786 & 0.044 & $4.40 \mathrm{E}-05$ & 0.0002 & $2.5 \times 10^{-5}$ & & 393.048 & 0.003 & $3.00 \mathrm{E}-06$ & 0.0008 & $4.2 \times 10^{-6}$ \\
\hline & 237.862 & 0.294 & $2.94 \mathrm{E}-04$ & 0.0011 & $2.6 \times 10^{-5}$ & & 390.71 & 0.003 & $3.00 \mathrm{E}-06$ & 0.0009 & $5.8 \times 10^{-6}$ \\
\hline \multirow[t]{5}{*}{$\mathbf{N i}$} & 231.604 & 0.064 & $6.40 \mathrm{E}-05$ & 0.001 & $2.8 \times 10^{-5}$ & \multirow[t]{3}{*}{ Zn } & 213.856 & 0.028 & 2.80E-05 & 0.001 & $6.0 \times 10^{-6}$ \\
\hline & 221.648 & 0.042 & $4.20 \mathrm{E}-05$ & 0.002 & $2.5 \times 10^{-5}$ & & 206.2 & 0.113 & $1.13 \mathrm{E}-04$ & 0.004 & $9.0 \times 10^{-5}$ \\
\hline & 232.003 & 0.103 & $1.03 \mathrm{E}-04$ & 0.001 & $6.5 \times 10^{-5}$ & & 202.613 & 0.035 & $3.50 \mathrm{E}-05$ & 0.001 & $1.0 \times 10^{-5}$ \\
\hline & 227.021 & 0.265 & $2.65 \mathrm{E}-04$ & 0.011 & 0.0005 & \multirow[t]{7}{*}{ Al } & 396.152 & 5.824 & $5.82 \mathrm{E}-03$ & 0.0025 & $2.5 \times 10^{-5}$ \\
\hline & 300.249 & 0.2 & $2.00 \mathrm{E}-04$ & 0.004 & $7.2 \times 10^{-5}$ & & 394.401 & 0.231 & 2.31E-04 & 0.0037 & $6.1 \times 10^{-5}$ \\
\hline \multirow[t]{5}{*}{$\mathrm{Cu}$} & 324.754 & 0.04 & $4.00 \mathrm{E}-05$ & 0.0001 & $4.5 \times 10^{-6}$ & & 308.215 & 0.113 & $1.13 \mathrm{E}-04$ & 0.008 & $4.1 \times 10^{-5}$ \\
\hline & 327.396 & 0.68 & $6.80 \mathrm{E}-04$ & 0.0009 & $8.0 \times 10^{-6}$ & & 309.271 & 0.134 & $1.34 \mathrm{E}-04$ & 0.097 & $2.1 \times 10^{-5}$ \\
\hline & 224.7 & 0.075 & $7.50 \mathrm{E}-05$ & 0.0015 & $2.7 \times 10^{-5}$ & & & & & & \\
\hline & 219.226 & 0.123 & $1.23 \mathrm{E}-04$ & 0.0118 & $7.6 \times 10^{-5}$ & & & & & & \\
\hline & 219.958 & 0.226 & $2.26 \mathrm{E}-04$ & 0.0069 & $6.4 \times 10^{-5}$ & & & & & & \\
\hline
\end{tabular}

used for its determination in a $\mathrm{Zr}$ matrix with a suitable correction factor as indicated in Table IV.

\section{Si}

The analytical lines of $\mathrm{Si}$ at $212.412 \mathrm{~nm}$ and $251.612 \mathrm{~nm}$ were least interfered by $\mathrm{Zr}$ and also had low, comparable detection limits. Use of the $152.672 \mathrm{~nm}$ and $288.158 \mathrm{~nm}$ lines are not recommended since their spectral interference is not moderate.
Sr

The Sr lines at $407.771 \mathrm{~nm}$ and $421.552 \mathrm{~nm}$ showed a negligibly small spectral interference from $\mathrm{Zr}$, but the $421.552 \mathrm{~nm}$ line showed a detection limit of one order of magnitude lower.

\section{$\mathrm{K}$ and $\mathrm{Li}$}

Even though the analytical line of $766.491 \mathrm{~nm}$ for $\mathrm{K}$ was interfered moderately, the Li $670.780 \mathrm{~nm}$ line showed practically no interference from $\mathrm{Zr}$.

\section{Eu}

The four studied analytical lines of $\mathrm{Eu}(420.505 \mathrm{~nm}, 381.967 \mathrm{~nm}$, $393.048 \mathrm{~nm}$, and $390.710 \mathrm{~nm}$ ) were practically interference-free and also had attractive detection limits $(420.505 \mathrm{~nm}-0.0006 \mu \mathrm{g} / \mathrm{mL}$, $381.967 \mathrm{~nm}-0.0001 \mu \mathrm{g} / \mathrm{mL}$, $393.048 \mathrm{~nm}-0.0008 \mu \mathrm{g} / \mathrm{mL}$, and $390.710 \mathrm{~nm}-0.0009 \mu \mathrm{g} / \mathrm{mL}$ ). 


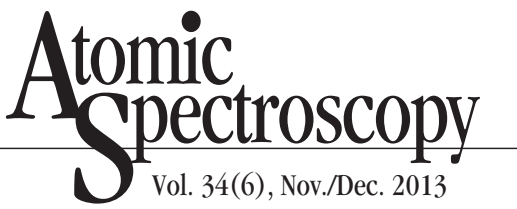
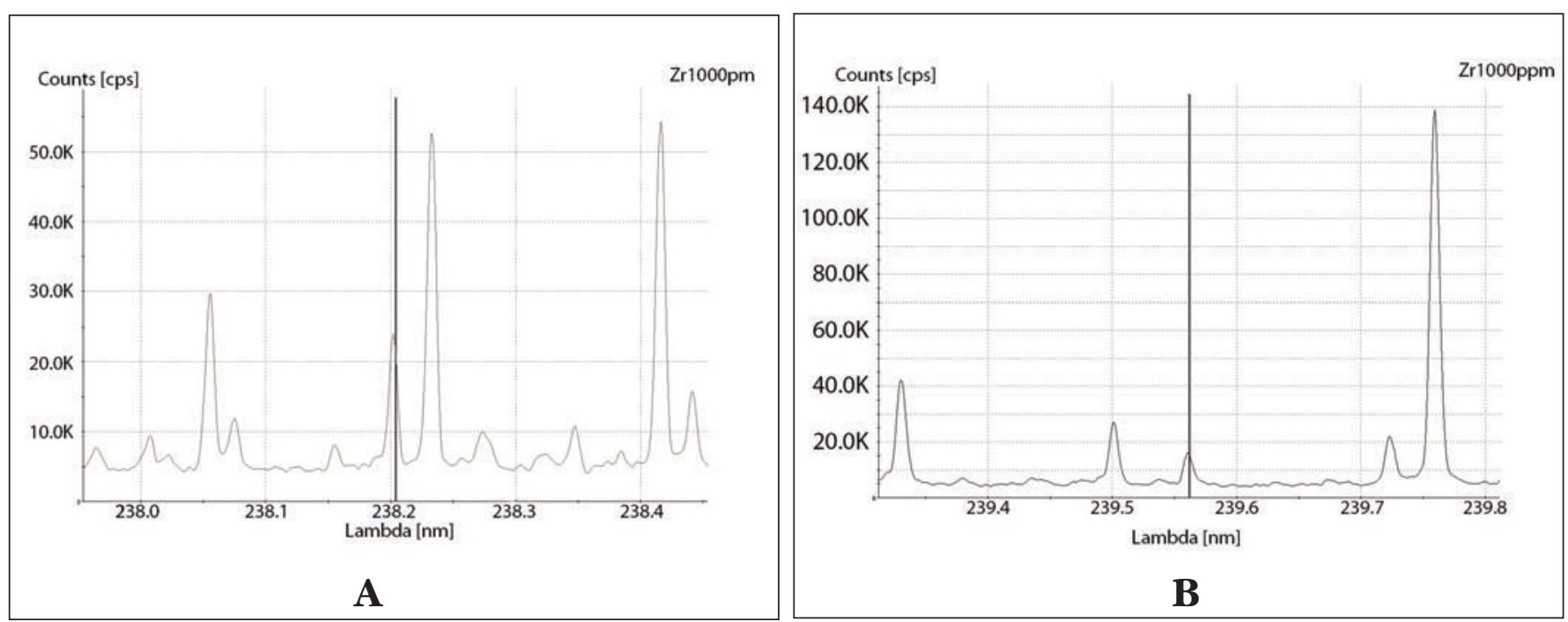

Fig. 3 (A and B). Contributions of $1000 \mu \mathrm{g} / \mathrm{mL}$ of $\mathrm{Zr}$ on the $238.204 \mathrm{~nm}$ (A) and $239.562 \mathrm{~nm}$ (B) analytical lines of Fe.

Zn

The analytical lines of $\mathrm{Zn}$ at $213.856 \mathrm{~nm}$ and $206.200 \mathrm{~nm}$ were found to be relatively interferencefree and had better detection limits $(0.001 \mu \mathrm{g} / \mathrm{mL}$ and $0.004 \mu \mathrm{g} / \mathrm{mL}$, respectively), whereas $202.613 \mathrm{~nm}$ and 334.502 showed moderate and strong interference from $\mathrm{Zr}$.

\section{Al}

Even though the $\mathrm{Al}$ analytical line at $396.152 \mathrm{~nm}$ was found to be the best analytical line, it showed strong spectral interference from $\mathrm{Zr}$, while the Al lines at 394.401 $\mathrm{nm}, 308.215 \mathrm{~nm}$, and $309.271 \mathrm{~nm}$ showed moderate spectral interference, and the $394.401 \mathrm{~nm}$ line showed the lowest detection limit. The two $\mathrm{Al}$ lines at $167.078 \mathrm{~nm}$ and $176.641 \mathrm{~nm}$ were strongly interfered by $\mathrm{Zr}$ and found to have comparably poor detection limits.

From these studies it can be concluded that the analytical line with moderate spectral interference can be used for the determination of analytes with suitable correction factors, while lines with strong interference should be disregarded for the determination of trace metallic impurities in a $\mathrm{Zr}$ matrix.

\section{Development of Method for the Determination of Analytes Without Chemical Separation}

Based on the above spectral interference study, it was found that the $257.611 \mathrm{~nm}$ line for $\mathrm{Mn}$; $230.786 \mathrm{~nm}$ line for $\mathrm{Co} ; 231.604$ $\mathrm{nm}$ and $221.648 \mathrm{~nm}$ lines for $\mathrm{Ni}$; $324.754 \mathrm{~nm}$ line for $\mathrm{Cu} ; 417.206$ $\mathrm{nm}$ line for $\mathrm{Ga} ; 212.412 \mathrm{~nm}$ and $251.612 \mathrm{~nm}$ lines for $\mathrm{Si} ; 421.552$ $\mathrm{nm}$ line for $\mathrm{Sr} ; 670.780 \mathrm{~nm}$ line for $\mathrm{Li} ; 420.505 \mathrm{~nm}, 381.967 \mathrm{~nm}$, $393.048 \mathrm{~nm}$, and $390.710 \mathrm{~nm}$ lines for $\mathrm{Eu}$; and the $213.856 \mathrm{~nm}$ and $206.200 \mathrm{~nm}$ lines for $\mathrm{Zr}$ can be used for the determination of these analytes without requiring any kind of separation.

Synthetic samples were prepared and the method was validated. It was observed that $\mathrm{Mn}, \mathrm{Co}, \mathrm{Ni}, \mathrm{Cu}$, $\mathrm{Ga}, \mathrm{Si}, \mathrm{Sr}, \mathrm{Li}, \mathrm{Eu}$, and $\mathrm{Zn}$ can be determined in a $\mathrm{Zr}$ matirx without chemical separation up to $0.1 \mu \mathrm{g} / \mathrm{mL}$. The analytical results as listed in Table $\mathrm{V}$ were found to be satisfactory. These results were further compared with two routinely employed methods: (a) Chemical separation of the $\mathrm{Zr}$ matrix with 30\% TBP-dodecane, followed by feeding the aqueous phase into the plasma for the determination of the analytes at trace levels and (b) determination of the analytes in a solid $\mathrm{ZrO}_{2}$ matrix using the d.c. arc carrier distillation technique. The results were found to be satisfactory.

The overall recovery of a method should be within $90-110 \%$. In the present method, it was found that the mean values for $\mathrm{Ni}$ and Li suggested a \% recovery for these elements in synthetic samples at $120 \%$. The true value, i.e., amount added, was found to follow within the concentration range specified in Table $\mathrm{V}$ with a confidence level of $99.99 \%(3 \sigma)$. In the d.c. arc carrier distillation technique, it was also observed that the confidence intervals were mostly more than those of ICP-AES, reflecting lesser precision of the former technique due to arc wandering. Additionally, for synthetic sample 1, the $\%$ recovery for all the elements was in the expected range of $90-110 \%$, while for synthetic sample 2, $\mathrm{Ni}$ and $\mathrm{Li}$ were found to be exceptions. This may be due to analytical errors, which generally increase in the lower level of detection compared to the higher concentration values. 
TABLE V

Validation of Methodology With Synthetic Samples and Comparison with Routinely Used Methods

\begin{tabular}{ccccc|cccc}
\hline \multicolumn{3}{c}{ Synthetic Sample-1 } & \multicolumn{4}{c}{ Synthetic Sample-2 } \\
\hline $\begin{array}{c}\text { Metal } \\
\text { Ion }\end{array}$ & $\begin{array}{c}\text { Amount } \\
\text { Added }\end{array}$ & $\begin{array}{c}\text { Present } \\
\text { Method } \\
\text { Separation } \\
(\mu \mathrm{g} / \mathrm{mL})\end{array}$ & $\begin{array}{c}\text { ICP-AES } \\
\text { After } \\
\text { Distillation } \\
(\mu \mathrm{g} / \mathrm{mL})\end{array}$ & $\begin{array}{c}\text { D.C. Arc } \\
\text { Carrier } \\
(\mu \mathrm{g} / \mathrm{mL})\end{array}$ & $\begin{array}{c}\text { Amount } \\
\text { Added }\end{array}$ & $\begin{array}{c}\text { Present } \\
\text { Method }\end{array}$ & $\begin{array}{c}\text { ICP-AES } \\
\text { After } \\
\text { Separation } \\
(\mu \mathrm{g} / \mathrm{mL})\end{array}$ & $\begin{array}{c}\text { D.C. Arc } \\
\text { Carrier } \\
\text { Distillation } \\
(\mu \mathrm{m} / \mathrm{mL})\end{array}$ \\
\hline $\mathrm{Mn}$ & 0.5 & $0.51 \pm 0.04$ & $0.47 \pm 0.04$ & $0.53 \pm 0.06$ & 0.1 & $0.11 \pm 0.03$ & $0.13 \pm 0.05$ & $0.11 \pm 0.06$ \\
$\mathrm{Co}$ & 0.5 & $0.49 \pm 0.02$ & $0.51 \pm 0.03$ & $0.47 \pm 0.07$ & 0.1 & $0.09 \pm 0.03$ & $0.09 \pm 0.03$ & $0.09 \pm 0.06$ \\
$\mathrm{Ni}$ & 0.5 & $0.51 \pm 0.03$ & $0.52 \pm 0.02$ & $0.49 \pm 0.06$ & 0.1 & $0.12 \pm 0.02$ & $0.10 \pm 0.01$ & $0.10 \pm 0.05$ \\
$\mathrm{Cu}$ & 0.5 & $0.50 \pm 0.01$ & $0.48 \pm 0.03$ & $0.52 \pm 0.06$ & 0.1 & $0.10 \pm 0.01$ & $0.12 \pm 0.05$ & $0.13 \pm 0.06$ \\
$\mathrm{Ga}$ & 0.5 & $0.49 \pm 0.03$ & $0.51 \pm 0.02$ & $0.47 \pm 0.05$ & 0.1 & $0.09 \pm 0.02$ & $0.08 \pm 0.03$ & $0.08 \pm 0.07$ \\
$\mathrm{Si}$ & 0.5 & $0.53 \pm 0.03$ & $0.48 \pm 0.04$ & $0.53 \pm 0.06$ & 0.1 & $0.11 \pm 0.03$ & $0.12 \pm 0.05$ & $0.12 \pm 0.05$ \\
$\mathrm{Sr}$ & 0.5 & $0.51 \pm 0.02$ & $0.49 \pm 0.03$ & $0.52 \pm 0.07$ & 0.1 & $0.11 \pm 0.01$ & $0.08 \pm 0.03$ & $0.12 \pm 0.04$ \\
$\mathrm{Li}$ & 0.5 & $0.52 \pm 0.03$ & $0.51 \pm 0.03$ & $0.48 \pm 0.06$ & 0.1 & $0.12 \pm 0.02$ & $0.12 \pm 0.05$ & $0.11 \pm 0.06$ \\
$\mathrm{Eu}$ & 0.5 & $0.51 \pm 0.01$ & $0.52 \pm 0.03$ & $0.47 \pm 0.05$ & 0.1 & $0.09 \pm 0.01$ & $0.12 \pm 0.04$ & $0.08 \pm 0.05$ \\
$\mathrm{Zn}$ & 0.5 & $0.50 \pm 0.03$ & $0.49 \pm 0.02$ & $0.48 \pm 0.07$ & 0.1 & $0.11 \pm 0.03$ & $0.12 \pm 0.03$ & $0.10 \pm 0.05$ \\
\hline
\end{tabular}

\section{CONCLUSION}

A systematic study was carried out to understand the spectral interference of zirconium on 14 analytes (Mn, Fe, Ga, In, Sr, K, Li, $\mathrm{Eu}, \mathrm{Co}, \mathrm{Zn}, \mathrm{Ni}, \mathrm{Cu}, \mathrm{Al}$, and $\mathrm{Si}$ ). The interference-free analytical lines of these elements were identified and the analytical performance (detection limits, sensitivity, etc.) studied. An analytical method was also developed for the determination of zirconium by ICP-AES, which includes identification of the suitable analytical lines, establishing the calibration curves, and evaluating the sensitivity and detection limits of $\mathrm{Zr}$. It was observed that except for the $339.198 \mathrm{~nm}$ line (saturates beyond $200 \mu \mathrm{g} / \mathrm{mL}$ ), the other three studied analytical lines (343.823nm, $257.139 \mathrm{~nm}$, and $272.262 \mathrm{~nm}$ ) can be used for $\mathrm{Zr}$ determination with $\sim 5 \%$ RSD.

In the present study, the following analytical lines were found to be appropriate for the determination of trace constituents in a nuclear grade $\mathrm{Zr}$ matrix: the $257.611 \mathrm{~nm}$ line for $\mathrm{Mn} ; 259.941 \mathrm{~nm}$ and $261.187 \mathrm{~nm}$ lines for Fe; $230.786 \mathrm{~nm}$ line for Co; $231.604 \mathrm{~nm}$ and $221.648 \mathrm{~nm}$ lines for $\mathrm{Ni}$; $324.754 \mathrm{~nm}$ line for $\mathrm{Cu} ; 417.206 \mathrm{~nm}$ line for $\mathrm{Ga} ; 230.606 \mathrm{~nm}$ line for In; $212.412 \mathrm{~nm}$ and $251.612 \mathrm{~nm}$ lines for $\mathrm{Si} ; 421.552 \mathrm{~nm}$ line for $\mathrm{Sr}$; $766.491 \mathrm{~nm}$ line for $\mathrm{K} ; 670.780 \mathrm{~nm}$ line for $\mathrm{Li}$; $420.505 \mathrm{~nm}, 381.967 \mathrm{~nm}$, $393.048 \mathrm{~nm}$ and $390.710 \mathrm{~nm}$ lines for $\mathrm{Eu} ; 213.856 \mathrm{~nm}$ and $206.200 \mathrm{~nm}$ lines for $\mathrm{Zn}$, and the $394.401 \mathrm{~nm}$ line for $\mathrm{Al}$.

Based on the interference study, a suitable methodology was developed for the determination of $\mathrm{Mn}$, $\mathrm{Co}, \mathrm{Ni}, \mathrm{Cu}, \mathrm{Ga}, \mathrm{Si}, \mathrm{Sr}, \mathrm{Li}, \mathrm{Eu}$, and $\mathrm{Zn}$ at trace levels without using any chemical or physical separation, while for $\mathrm{Fe}, \mathrm{Al}, \mathrm{K}$, and $\mathrm{In}$, appropriate correction factors should be employed.

\section{ACKNOWLEDGMENT}

The authors acknowledge the constant supports and encouragement of Dr. S.V. Godbole, Head, Actinide Spectroscopy Section, and Dr. A. Goswami, Head, Radiochemistry Division, Bhabha Atomic Research Centre, Mumbai, India.

Received August 21, 2013 


\section{REFERENCES}

1. T.R. Bangia, B.A. Dhawale, V.C. Adya, and M.D. Sastry, Fresenius J. Anal. Chem. 332, 802 (1988).

2. N. K. Porwal, A. A. Argekar, P. J. Purohit, A. G. Page, and M. D. Sastry, Fresenius J. Anal. Chem. 338, 255 (1990).

3. A. G. Page, K. H. Madraswala, S. V. Godbole, Madhuri J. Kulkarni, Vanita S. Mallapurkar, and B. D. Joshi, Fresenius Z. Anal. Chem. 315, 38 (1983).

4. A.G. Page, S.V. Godbole, S. Deshkar, Y. Babu, and B.D. Joshi, Fresenius J. Anal. Chem. 287, 304 (1977).

5. A.G.I. Dalvi, C.S. Deodhar, T.K. Seshagiri, M.S. Khalap, and B.D. Joshi, Talanta 25, 665 (1978).

6. T.G. Bangia, B.A. Dhawale, V.C. Adya, and M.D. Sastry, Fresenius J Anal Chem. 332, 802 (1988).

7. K. Satyanarayana and S. Durani, J. Radioanal. Nucl. Chem. 285(3), 659 (2010).

8. B. Rajeswari, B.A. Dhawale, T.R. Bangia, J.N. Mathur, and A.G. Page, J. Radioanal. Nucl. Chem. 254(3), 479 (2002).

9. A. Sengupta, M. J. Kulkarni, and S. V. Godbole, J. Radioanal. Nucl. Chem. (2011), DOI 10.1007/s10967-011-1222-8

10. A.A. Argekar, M.J. Kulkarni, J.N. Mathur, and A.G. Page, Talanta 56(4), 591 (2002).

11. C. Mahan, S. Bonchin, D. Figg, D. Gcrth, and C. Collier, J. Radioanal. Nucl. Chem. 15(8), 929 (2000).

12. R.K. Malhotra, and K. Satyanarayana, Talanta 50(3), 601 (1999).

13. S. Marin, S. Cornejo, C. Jara, and N. Duran, Fresenius' J. Anal. Chem. 355(5-6), 680 (1996).
14. E.A. Huff, Spectrochim. Acta Part B: At. Spectrosc. 42(1-2), 275 (1987).

15. E.A. Huff E.A.and D.L.Bowers, Appl. Spectrosc. 43(2), 223 (1989).

16. A. Sengupta, B. Rajeswari, R.M. Kadam, and R. Acharya, At. Spectrosc. 32(5), 200 (2011).

17. A. Sengupta, V.C. Adya, Mithelesh Kumar, S.K. Thulasidas, S.V. Godbole, and V.K. Manchanda, At. Spectrosc. 32(2), 49 (2011).

18. Arijit Sengupta, B. Rajeswari, R.M. Kadam, and S.V. Godbole, At. Spectrosc. 33(2), 48 (2012).

19. O.J. Kond, K. Domen and I.J. Maruyak, Faraday Trans. 88, 2095 (1992).

20. R.M. Li, Z.S. Li and Y.F. Xin, Appl. Sci. Technol. 9, 52 (2001).

21. N.E. Gordon, Jr., and R.M. Jacobs, Anal. Chem. 25, 1605 (1953).

22. C.L. Easterday, Anal. Chem. 31(11), 1867 (1959).

23. I. Steffan and G. Vujicic, J. Anal. At. Spectrom. 9, 785 (1994).

24. X. Ma and Y. Li, Anal. Chim. Acta 579, 47 (2006).

25. M. Watanabe, A. Horiki and T. Uchidab, Anal. Chim. Acta 416, 117 (2000).

26. O. Acar, Anal Sci. 22(5), 731 (May 2006).

27. Jibrin Sabo Suleiman, Bin $\mathrm{Hu}$, Xuli Pu, Chaozhang Huang, and Zucheng Jiang, Microchim. Acta 159( 3-4), 379 (2007).

28. S. Chen, D. Lu, Z. Hu, and B. Wu, Spectrochim. Acta Part B: 60(4), 537 (2007).

29. Krivan, Viliam; Janickova, Petra, Anal. Bioanal. Chem. 382(8), 1949 (2005).

\section{Amic $_{\text {Soctroscopy }}^{\text {tomi }}$}

30. Arijit Sengupta, V.C. Adya, T.K. Seshagiri, and S.V. Godbole, At. Spectrosc. 34(2), 53 (2013).

31. Arijit Sengupta, V.C. Adya, and S.V. Godbole, J. Radioanal. Nucl. Chem, (2013), DOI 10.1007/s10967-013-2520-0. 